\title{
When States Crack Down on Human Rights Defenders
}

\author{
Kristin M. Bakke \\ Department of Political Science, University College London \& \\ Peace Research Institute Oslo \\ Corresponding Author: kmbakke@ucl.ac.uk \\ Neil J. Mitchell \\ Department of Political Science, University College London \\ Hannah M. Smidt \\ Institute of Political Science, University of Zurich \& \\ GIGA German Institute of Global and Area Studies
}

December 2019

Forthcoming in International Studies Quarterly

(accepted October 1, 2019)

\begin{abstract}
Research suggests that civil society mobilization together with the ratification of human rights treaties put pressure on governments to improve their human rights practices. An unexplored theoretical implication is that pressure provokes counter-pressure. Instead of improving treaty compliance, some governments will have an interest in de-mobilizing civil society to silence their critics. Yet we do not know how and to what extent this incentive shapes governments' policies and practices regarding civil society organizations. We argue and show - using a new global database of government-sponsored restrictions on civil society organizations - that when governments have committed to human rights treaties and, at the same time, continue to commit severe human rights abuses, they impose restrictions on civil society groups to avoid monitoring and mitigate the international costs of abuses.
\end{abstract}

Acknowledgements: Kristin M. Bakke and Neil J. Mitchell acknowledge generous funding from the British Academy (grant number SG152265). The authors would like to thank the following for helpful feedback on this project: Niheer Dasandi, Dom Perera, William Reed, James Savage, Scott Straus, and Gary Uzonyi, the ISQ editors and anonymous reviewers, as well as colleagues in the UCL Conflict \& Change research cluster, participants at the UCL Global Governance Institute's 2017 workshop on "Restrictions on Civil Society and the Free Flow of Information," the members of our panels at the 2016 annual meeting of the APSA in Philadelphia and the 2018 annual meeting of the International Studies Association in San Francisco, and seminar and workshop participants at the University of Birmingham, the University of Essex, the University of Glasgow, and Oxford University. 


\section{Introduction}

Why do states use restrictive policies and practices against civil society organizations? There is over two decades of research suggesting that human rights monitoring activities by civil society improve states' compliance with human rights commitments. Pressure on governments to live up to international human rights norms comes both from information flowing from 'below,' from civil society organizations at the national level, and from 'above,' from other states and international organizations acting upon the information from local organizations (Keck and Sikkink 1998; Risse and Sikkink 1999; Landman 2005; Hafner-Burton and Tsutsui 2005; Simmons 2009; Krain 2012; Murdie and Davis 2012; Smith-Cannoy 2012; Brysk 2013; Risse, Ropp, and Sikkink 2013). But what about pressure exerted in the other direction, by state governments against those monitoring their activities? We examine states' counter-measures against monitoring by civil society and investigate the conditions under which international human rights treaties lead governments to employ restrictive practices and policies on civil society.

We define civil society organizations as organizations that are not part of the government or the for-profit sector, and which monitor government behavior and advocate for human rights. These organizations may be operating both domestically and internationally. Among the civil society organizations that operate domestically, we include local branches of international organizations, such as local chapters of Amnesty International, which may alert the international 'parent' organization to repression. In recent years, governments have become increasingly inventive in their restrictive practices and policies. For example, the Russian government has since 2012 restricted, by law, the access of local civil society organizations to foreign aid. In 2015, President Vladimir Putin signed legislation that allows the authorities to shut down "undesirable" organizations (Luhn 2015; Tavernise 2015). "Undesirable" organizations were reported to include Human Rights Watch and 
Amnesty International, as well as the Carnegie Moscow Center, and the well-known Russian human rights organization Memorial. In July 2015, Russian law enforcement officials raided the offices and homes of staff of Golos, a local non-governmental organization that monitors elections (Nechepurenko 2015), and the Committee Against Torture had to close its operations after the Ministry of Justice listed it as a "foreign agent" (Litvinova 2015). Russia is not alone. In Thailand in September 2016, Amnesty International was warned by the police that its people risked arrest for visa violations if they held an event publicizing a report on torture. Amnesty called off the event (Holmes 2016). More generally, United Nations (UN) special rapporteurs describe the gravity of the problem of harassment, intimidation, and reprisals and observed the "visible shrinking of civil society" (Sekaggya 2013).

We argue that governments restrict the activities of civil society organizations in order to hide non-compliance with human rights norms and commitments. Existing research on human rights treaties describes a "compliance gap" between governments' treaty commitments and their human rights practices (Hathaway 2002; Hafner-Burton 2008; Payne and Abouharb 2016). Yet, if treaty ratification is accompanied by civil society monitoring and mobilization, violating human rights becomes more costly as civil society organizations reveal the gap between treaty provisions and government performance (Hafner-Burton and Tsutsui 2005; Landman 2005; Simmons 2009), thereby sometimes improving government compliance with international human rights standards (Neumayer 2005). Relatedly, the literature on transnational advocacy shows that international shaming campaigns positively influence governments' human rights record, but only if local civil society organizations exist and transmit information on governments' non-compliance to international organizations (Meernik, Aloisi, Sowell, and Nichols 2012; Murdie and Davis 2012). A general theoretical implication of this research — which we explore in this manuscript—is that governments committing human rights abuses and anticipating international costs for doing so may have 
an interest in de-mobilizing civil society if they are unable or unwilling to guarantee human rights. To maintain control of insincere or naively assumed international human rights commitments and to keep information about their most severe human rights violations private, states seek discrete ways-for example, registration difficulties, travel obstructions, visa delays, or smearing civil society activists — to manage the monitoring and mobilization activities of civil society organizations.

Using our new dataset of government-imposed policies and practices against civil society, our analysis of a global set of countries from 1994 to 2014 provides support for this argument. States that have ratified human rights treaties - the International Covenant of Civil and Political Rights (ICCPR) and the Convention Against Torture (CAT) -impose more restrictions on civil society if they have severe human rights violations to hide. Non-ratifying governments do not increase restrictions on civil society if they commit severe abuses. These findings are robust if we account for endogenous treaty commitments, selection effects, omitted variables, reporting bias, or use alternative measures of key concepts.

This article contributes to the literatures on transnational advocacy, international human rights treaties, and state repression. First, while civil society monitoring and resulting pressures for compliance are conventionally expected to improve performance (e.g. Keck and Sikkink 1998), we show that an alternative is for the state to silence monitoring by civil society groups. As such, our study suggests that one needs to consider how governments treat civil society groups to understand the impact of civil society mobilization and human rights treaties on human rights practices. Other researchers also point out that governments have choices and can adapt their strategies of repression to minimize the pressures resulting from international treaties. So far, researchers have considered strategic adaptation in terms of either augmenting repression (Conrad and Ritter 2013; Ritter and Conrad 2016) or changing to less conspicuous types of repression (McCormick and Mitchell 1997, 514; Payne and 
Abouharb 2016). We contribute to this line of research, both theoretically and empirically, by focusing on targeted restrictions on civil society and governments' attempts to hide their misbehavior and alleviate pressure from international human rights regimes. Second, researchers have begun to track shrinking spaces for civil society. Data on laws restricting NGO financing is an important step, but as Dupuy, Ron, and Prakash $(2016,307)$ point out, we have lacked information on the actual practices of states and non-legal restrictions that interfere with civil society monitoring. ${ }^{1} \mathrm{We}$ contribute a new dataset on the range of specific policies and practices directed at international and domestic civil society organizations for all countries in the world between 1994 and 2014. The Civil Society Restrictions Dataset accounts for the operational, bureaucratic, and funding costs imposed on organized civil society, including measures of travel restrictions, visa difficulties, surveillance, censorship of publications, and threatening or harassing activists. This disaggregated information on the variety of restrictive policies and practices used by states complements the legal restriction data as well as the V-Dem project approach, which captures some restrictions on an ordinal scale using expert assessments, and the CIRI Freedom of Association and Assembly data, which are focused more broadly on citizens' rights (see Appendix J for empirical comparisons). Finally, there has been only one systematic cross-national study of restrictions on civil society organizations, showing that foreign funding restrictions are more likely if governments receive larger amounts of foreign development aid (Dupuy, Ron, and Prakash 2016). We build on the notion that international pressure is an important factor in explaining government-sponsored restrictions, but we shift the focus to human rights treaties and

\footnotetext{
${ }^{1}$ See Glasius (2018) for a discussion of "illiberal practices." For the legal framework that affects civil society organizations, the International Center for Not-for-Profit Law (ICNL) has data for some 50 countries on foreign funding restrictions. Dupuy, Ron, and Prakash (2016) used ICNL and other sources to construct a dataset on legal restrictions on foreign aid to NGOs for 153 countries for 1993-2012 (see also Christensen and Weinstein 2013). In turn, as restrictions are a response to civil society pressure, so civil society and the international community will respond to restrictions by taking measures to protect human rights defenders (see also Bennett, Ingleton, Nah, and Savage 2015). In further work, we explore how civil society organizations adapt to state restrictions (Smidt, Perera, Mitchell, and Bakke 2020).
} 
transnational advocacy and expand the analysis by examining a comprehensive set of restrictive policies and practices against civil society organizations.

In the remainder, we develop our argument: given, as earlier research has shown, civil society organizations pressure governments to live up to their human rights treaty obligations, governments will have an incentive to increase the costs of this monitoring and restrict the flow of information about their poor performance. We then discuss our research design, accounting for reporting bias and reverse causation, and present findings in line with our main argument. We conclude by discussing implications for theory and policy.

\section{Substantive Background}

Our argument for why governments impose restrictions on civil society organizations draws on insights from research on international human rights treaties, transnational advocacy, and state repression. Work on the effects of human rights treaties points to a compliance gap between governments' treaty commitments and their human rights performance (Hathaway 2002; Hafner-Burton and Tsutsui 2005; Payne and Abouharb 2016). Emphasizing the expressive function of treaty commitments, Hathaway (2002) suggests that treaty ratification alleviates internal and external pressures for compliance and human rights improvements. Treaty commitments can be window-dressing and exacerbate negative human rights practices (Hafner-Burton and Tsutsui 2005). Yet while treaty ratification can be an “empty promise," not all governments can ignore their commitments (Lupu 2013). Violating human rights becomes costly when treaty ratification is accompanied by civil society monitoring. Civil society organizations can reveal the gap between treaty provisions and government practices (Hafner-Burton and Tsustui 2005; Landman 2005; Simmons 2009). Treaty ratification can improve respect for human rights when there are non-governmental organizations that monitor government behavior and have international linkages. These non- 
government organizations can mobilize pressure both from below, for example, from domestic constituencies, and pressure from above, for example, from international organizations, third-party states, and individuals (Risse, Ropp, and Sikkink 2013). Yet, human rights treaties are less effective where governments rule autocratically and inhibit civil society activity (Neumayer 2005). Indeed, Dai (2005; 2013) explicates this role of civil society groups in mobilizing pressures from below. According to her "domestic constituency mechanism," beyond the electoral leverage behind pro-compliance interests, the amount of information that pro-compliance interest groups possess about treaty-relevant government policies is crucial for government compliance with human rights rights. ${ }^{2}$ Ritter and Conrad (2016) add that human rights treaty ratification can also mobilize pressure from below. In states where domestic courts are weak, protesters mobilize in the expectation that treaty ratification paired with domestic dissent significantly increases litigation costs for human rights-violating governments. These costs, in turn, can lower government abuses. Overall, the activity of civil society organizations - their ability to monitor and collect information on government behavior as well as their mobilized dissent - are crucial for whether governments incur domestic costs for non-compliance.

Beyond domestic constituency mechanisms, research on international "naming and shaming" campaigns details the role of civil society in mobilizing pressure on governments from above. Pressure from international organizations on governments, that 'boomerangs' from civil society mobilization nationally, improves human rights (Keck and Sikkink 1998). Domestic civil society organizations supply information to international organizations that then name and shame governments. Meernik, Aloisi, Sowell, and Nichols $(2012,233)$ find that the increasing presence of local human rights organizations "is the critical link between

\footnotetext{
${ }^{2}$ Lupu (2013) also emphasizes the role of information on human rights violations. He argues that human rights treaty ratification improves freedom of speech, association, assembly, and religion but not physical integrity rights violations because it is easier to obtain information on violations of these freedoms.
} 
the local and the international," generating international attention for government human rights abuses. Moreover, the presence of domestic civil society organizations can also render shaming by international civil society effective in achieving government compliance with international human rights norms (Murdie and Davis 2012). ${ }^{3}$ If domestic civil society can monitor government behavior and form networks with international organizations, governments face reputational and possibly trade, aid, and investment costs if they commit human rights violations (Krain 2012).

As an alternative to improving compliance with insincerely or naively assumed international human rights treaty commitments, governments may also strategically adapt. Having shown that domestic civil society organizations matter for effective international shaming, Murdie and Davis (2012) warn that an increasing number of governments restrict the operations of civil society. Conrad and Ritter (2013) argue that because treaty commitments encourage domestic pressure, they indirectly create incentives for governments to repress dissent (see also Ritter and Conrad 2016). Their empirical analyses, however, reveals that ratifying the Convention Against Torture (CAT) neither increases nor decreases repression by governments with low security in office and decreases levels of repression for government leaders that are securely in office. In related work, Payne and Abouharb (2016) find that governments, on average, do not improve their human rights behavior after they have ratified a human rights treaty. Noting the weak monitoring and enforcement mechanisms of the human rights regime, their study reveals that treaty member governments tend to shift repressive strategies from employing extrajudicial killings to forced disappearences, which are more difficult to link to the governments (cf. Hafner-Burton 2008). Assuming that some governments will continue to violate human rights despite having

\footnotetext{
${ }^{3}$ Yet, Murdie and Davis $(2012,15)$ also argue that human rights practices improve in response to shaming paired with international pressures from third parties, even in states with limited civil society presence.
} 
promised otherwise by ratifying international treaties, an unexplored theoretical implication is that governments will counter domestic pressure for compliance with the international human rights regimes. Governments use discrete bureaucratic and other measures to alleviate the pressure from civil society organizations operating within the boundaries of their state.

Research on restrictions against civil society and its funding has recognized the role of international leverage and linkages in determining government behavior towards civil society organizations. Brechenmacher and Carothers (2014; see also Carothers 2016) conceive of restrictions as a symptom of a state's pushback against the international promotion of democracy and human rights. Dupuy, Ron, and Prakash (2016) show that governments legally restrict foreign-funded civil society organizations in an attempt to curtail the influence of international aid on the growth of independent civil society organizaions, especially before national elections. And while Christensen and Weinstein (2013) argue that domestic concerns are paramount in driving vulnerable governments' decision to restrict civil society funding, they also suggest that anticipated international retaliation for such restrictions can restrain governments. This research reveals the links between, on the one hand, international actors and programs and, on the other hand, funding restrictions on civil society. Building on the broader literatures of transnational advocacy, human rights treaties and repression, we turn our attention to how restrictions depend on the interactive impact of government human rights practices and international human rights treaties. Expanding the focus beyond foreign funding restrictions, we collect and analyze new data on different types of restrictive policies and practices imposed on civil society for a global set of countries over time (1994-2014).

\section{Argument: Civil Society, Compliance, and Countermeasures}

Our argument is consistent with the transnational advocacy literature in that pressure 
from below, from civil society organizations, and from above, from the international human rights regime, increase government incentives to appear to be on their best behavior (e.g. Keck and Sikkink 1998; Risse and Sikkink 1999; Hendrix and Wong 2012; Krain 2012; Meernik, Aloisi, Sowell, and Nichols 2012; Murdie and Davis 2012; Brysk 2013; Risse, Ropp, and Sikkink 2013). However, we argue, rather than improving compliance with the international human rights regime, governments may also continue to violate human rights and hide them from international attention by restricting civil society organizations operating on their territory.

States commit to the international human rights regime in the knowledge that the monitoring of this regime is weak. ${ }^{4}$ While a state under "moral management" might keep human rights commitments voluntarily and forego repression (Baron 2009), the uneven record of human rights protection suggests that many states do not. States commit to protect human rights, but it may be an "empty promise" (Thomas 2001; Hafner-Burton and Tsutsui 2005; Hathaway 2002; Simmons 2009).

The international human rights regime is reliant on domestic constituencies for monitoring and detecting non-compliance with international treaties (e.g. Dai 2005; 2013). As Meernik, Aloisi, Sowell, and Nichols $(2012,240)$ put it: "Local offices of human rights organizations are repositories of information on human rights abuses (...) They collect, investigate, analyze, and disseminate information to advance the cause of human rights in their locale by calling attention to human rights violations (to the extent possible given local conditions)." NGOs inform human rights institutions and treaty bodies, as well as other governments on how a state carries out its international commitments. Earlier research, while noting that there are organizational biases of civil society actors (e.g. Bob 2005), shows that

\footnotetext{
${ }^{4}$ Governments have various motives for ratifying human rights treaties (Moravscik 2000; Vreeland 2008; Simmons 2009). The costs attached to such commitments - that is, showing a good human rights record-are lower with lower monitoring capacity on the part of the international community.
} 
more abusive states attract the attention of human rights organizations. Civil society organizations lower the auditing cost for the international community, including the major media outlets.

Existing research shows that ratification of human rights treaties with monitoring by civil society creates pressure for compliance. First, treaties such as the International Covenant of Civil and Political Rights (ICCPR) or the Convention Against Torture (CAT) facilitate monitoring by civil society organizations. Human rights treaties are important to civil society because, as Simmons $(2009,14)$ puts it, they "sharpen the focus on particular accepted and proscribed behaviors ... treaties constrain government because they help define the size of the expectations gap when government fail to live up to their provisions." That is, treaties provide a benchmark against which government behavior can be evaluated, and the core provisions of the most prominent human rights treaties, the ICCPR and CAT, are nonderogable. Second, these treaties also help to set the political agenda and induce civil society activities to demand compliance (Conrad and Ritter 2013). For example, domestic human rights activists may use UN human rights treaties to motivate their advocacy. As Thomas (2001) argues in analyzing the effect of the Helsinki Final Act, even if the commitment is "empty," it can generate local and transnational pressure for compliance (see also Snyder 2011). Third, human rights treaties can support domestic courts and therefore increase the litigation costs that government incur for abuse (Simmons 2009, 14-15; Conrad and Ritter 2013). Fourth, states that violate the norms to which they signed up undermine international human rights instruments. Thus, they can expect greater international indignation compared to states that never ratified a human rights treaty. Fifth, ratifying states are required to submit regular reports to treaty bodies, which invites attention from international media, other states, and the UN. Hence, information from civil society organizations contradicting government reports receives greater exposure. Overall, these arguments suggest that ratification of a 
human rights treaty invites additional pressures and reputational costs for governments that should incentivize them to appear to be on their best human rights-abiding behavior. ${ }^{5}$

Governments, fearing that civil society actors will expose their failure to live up to their human rights obligations, are expected to close the expectations gap and improve compliance with treaty commitments. As Keck and Sikkink $(1998,24)$ argue: "Once a government has publicly committed itself to a principle — for example, in favour of human rights or democracy—networks can use those positions, and their command of information, to expose distance between discourse and practice. This is embarrassing to many governments, which may try to save face by closing that distance.” More recently, researchers recognize that there is not one linear path to compliance and less repression (e.g. Dai 2013). Murdie and Davis $(2012,14)$ find that shaming by domestic and international groups together improves compliance with human rights commitments, but also observe that governments increasingly restrict civil society. ${ }^{6}$ Ritter and Conrad (2016) argue that increased mobilization may incentivize repression.

As this line of research suggests, governments have choices and not simply between more or less compliance. Governments can improve compliance or they can make their noncompliance more difficult to detect. Rather than forego repression, governments seek to hide their severe human rights violations from the international community through targeted counter-measures creating obstacles to detection. Although it is an international regime, there is a dimension that remains subject to the influence of government policy and practice. If, as the spiral theory and the boomerang argument suggests, information on victims and detailed monitoring depend on an information flow from local organizations and the incentivized

\footnotetext{
${ }^{5}$ In Appendix $\mathrm{H}$ we examine whether a similar logic holds for the Rome Statute that sets up the International Criminal Court. Empirical findings provide support for this extension of the argument.

${ }^{6}$ Again, we note that some studies also show that human rights treaty ratification leads states to strategically shift to specific types of violations (Hafner-Burton 2008; Payne and Abouharb 2016). We see this behavior as evidence for our argument that human rights treaties put additional pressure on states to hide their wrongdoing.
} 
domestic constituency, governments can impose registration difficulties, perform tax audits, censor publications of human rights organizations, and smear activists in an effort to manage the flow of information about severe human rights violations and the use of extrajudicial killing, torture, and disappearances. Governments can use these restrictive practices and policies to pre-emptively demobilize civil society in the period in which they commit severe violations and they can employ restrictions retrospectively to prevent civil society mobilization after severe violations have occured. In both scenarios, governments attempt to silence and restrict critical civil society organizations if they are unwilling or unable to improve their human rights behavior and face pressure to comply with treaty obligations:

Hypothesis: If governments are party to a human rights treaty and commit severe human rights violations, then they will impose more restrictions on civil society organizations compared to a) governments that are party to a treaty and commit few violations and b) governments that are not party to a treaty and commit severe violations.

In short, our argument assumes that states react to pressure from international human rights instruments and civil society. It takes as its point of departure two findings in earlier works: there is a gap between the behavior of states and the human rights norms that they have signed up to, and human rights violations are more costly when civil society is mobilized to monitor state behavior and states have previously ratified a human rights treaty. The paradox of the enormous growth and success of civil society organizations in providing high-quality information about physical integrity violations to the international community, coupled with most states agreeing these violations are contrary to international law, is the creation of an incentive for governments to silence these actors. This incentive will be strongest — and civil society at highest risk — in states ruled by "empty promisers" that ratify international agreements but frequently violate the norms to which they signed up. ${ }^{7}$

\footnotetext{
${ }^{7}$ While we argue that monitoring creates an incentive for government restrictions, we do not assume that restrictions are always effective in alleviating pressure to improve human rights performance. In fact, human
} 


\section{Research Design}

We examine our argument with a cross-national analysis of state-sponsored restrictions on civil society in 149 states between 1994 and $2014 .^{8}$

\section{Data}

Our data come from the the section on "Governmental Attitude Regarding International and Nongovernmental Investigation of Alleged Violations of Human Rights" in the country reports of the United States Department of State, Bureau of Democracy, Human Rights, and Labor. The reports identify government restrictions directed against groups active on human rights issues. For example, in Belarus in 2015:

Authorities harassed both registered and unregistered human rights organizations, subjected them to frequent inspections and threats of deregistration, reportedly monitored their correspondence and telephone conversations, and harassed family members of group leaders and activists (U.S. Department of State 2015).

Or from Guinea:

The government facilitated visits by a number of international human rights NGOs and generally cooperated with such organizations; however, none were permitted access to military prisons (U.S. Department of State 2009).

To date, no use has been made of this information on restrictions for systematic analysis. ${ }^{9}$ Existing datasets have information on foreign funding restrictions for 153 low and middle-income countries (Dupuy, Ron, and Prakash 2016) and the legal framework that affects civil society organizations, collected for some 50 countries (International Center for Not-for-Profit Law 2016). In addition, the V-Dem and the

\footnotetext{
rights treaty-ratifying governments may first try to hide physical integrity violations by restricting civil society and, in case restrictions are ineffective, take steps to improve their human rights record.

${ }^{8}$ The original data on restrictions on civil society includes 176 countries, but 27 countries are not in our analysis because of missing data on relevant covariates.

${ }^{9}$ Inter-coder reliability is high. For a stratified random sample of 186 country-year observations (strata=years), the rate of agreement between two coders is at 85 percent for harassment, at 88 percent for surveillance and above 92 percent for all other restriction types (cf. Appendix B).
} 
CIRI datasets provide aggregate measures of the situation of civil society organizations, which we use as robustness tests. The V-Dem project provides an ordinal experts-based measure for whether government attempts to repress civil society organizations (Pemstein 2015; Coppedge et al. 2017, 243). While our data relies on public reports and differentiates between various types of restrictive practices and policies (see list below), the V-Dem measure builds on information provided by country experts. It therefore provides an aggregate score of repression against civil society on a four-point ordinal scale ranging from 0 (repression on the scale of Stalinist Russia or Nazi Germany) to 4 (free to organize). The V-Dem measure is less suitable for our purpose of evaluating the extent and diversity of the range of more subtle restrictions to hide physical integrity rights violations. The V-Dem measure's reference to large scale repression and inclusion of arrests, public display of force, and disruption of public gatheringsimplies conceptual overlap with physical integrity rights abuses. Our disaggregated data is also distinct from the ordinal measure of "freedom of assembly and association" provided in the CIRI dataset, which ranges from 0 for severely restricted freedoms to 2 for freedoms of assembly and association being virtually unrestricted. That is, the CIRI measure does not only include repression targeting civil society organizations but also actions taken more broadly against political parties (Cingranelli, Richards, and Clay 2014). Our dataset permits analyses of the range of types of restrictions that states impose on civil society organizations.

\section{Dependent Variable}

Our dependent variable is the prevalence of restrictions on civil society organizations. We construct a count variable of the different types of restrictions, which captures the operational, bureaucratic, and funding costs imposed on organized civil 
society. It includes the following types of restrictions:

- banning specific civil society organizations,

- curtailing travel,

- restricting their visits to government sites,

- limiting their domestic funding sources,

- limiting their international funding sources,

- creating difficulties in obtaining visas or denying visas,

- creating difficulties in registering as civil society organizations,

- censoring their publications,

- harassing civil society activists, and

- surveilling civil society activists.

Figure 1 shows the distribution of restrictions across countries for 2014, with the level of restrictions particularly high in the Middle East, Eastern Europe (including Russia), and Central Asia. ${ }^{10}$ Half of the yearly observations in our sample show at least one restriction on civil society organizations' mobilization and operation. On average, there are 1.3 types of restrictions per country-year.

- Figure 1: Number of restrictions on civil society organizations (2014) -

Comparing our measure with the V-Dem measure of repression of civil society and the CIRI freedom of association measures, we find that our data are quite highly but not perfectly correlated with both the V-Dem data $(0.55$, p-value $=0.00)$ and CIRI

\footnotetext{
${ }^{10} \mathrm{We}$ exclude those country-years where independent civil society is fully banned and countries, thus, exclude themselves from the 'boomerang' process - that is where pressure cannot come from below. An outright ban is not a subtle restriction and may not deflect but attract attention from the international community if governments have ratified human rights treaties. However, in Appendix K, we show that results are substantively the same if we include those cases.
} 
data $($ rho $=0.52, p$-value $=0.00)$. Moreover, our measure also picks up on greater within-country, over-time variation compared to V-Dem and CIRI (see figures in Appendix J), suggesting that our nine-point scale of restrictions provides substantively meaningful nuance in describing how government treats civil society organizations.

\section{Main Explanatory Variables}

To measure physical integrity rights violations, we use the five-point ordinal measure from the Political Terror Scale (Gibney et al. 2016) and the latent Human Rights Score by Schnakenberg and Fariss (2014a; 2014b) as an alternative measure that corrects for over-time reporting changes (Fariss 2014). ${ }^{11}$ Both measures reflect the conceptual distinction between civil society restrictions and physical integrity rights violations. For example, the 2005 U.S. State Department report on Uganda states that, "human rights groups generally operated without government restriction, investigating and publishing their findings on human rights cases." Nevertheless, this report also records "unlawful killings, disappearances, (...) use of torture and abuse of suspects" of the Ugandan security forces. Figures 2 and 3 illustrate that there is a positive but not perfect correlation between human rights abuses and restrictions in the full sample. To the extent that human rights norms are considered to apply whether or not states have ratified a specific treaty, there will be pressure to comply and an incentive to restrict. But even among cases with severe human rights abuses (x-axis), there are several with no or only a few restrictions on civil society (y-axis). We measure abuses and restrictions contemporaneously because we do not expect one specific temporal ordering. Instead, we think that human rights treaty-ratifying governments will both pre-empt civil society monitoring when they commit abuses, and restrict civil society

\footnotetext{
${ }^{11}$ We use Fariss's measure as an alternative. See debate (Cingranelli and Filippov 2018; Fariss 2019).
} 
activity to cover up violations. In Online Appendix $\mathrm{M}$ we show that results are substantively the same if we lag human rights abuses and treaty ratification by one year and thus examine the covering-up purpose of restrictions.

- Figure 2. Joint distribution of the Political Terror Scale and the restriction count-

- Figure 3. Joint distribution of Fariss's abuses scores and the restriction count -

For human rights treaties, we use two binary variables for whether a state ratified the International Covenant of Civil and Political Rights (ICCPR) and the Convention Against Torture (CAT). ${ }^{12}$ These variables are interacted with the PTS and Fariss's latent human rights scores, respectively. We also show that results are robust for indicators for either treaty ratification and for a count of treaties (Appendix F). In the first year in our sample, 77 percent of the countries have ratified ICCPR, increasing over the period to 90 percent. Only 53 percent of the countries have ratified the CAT in the first year in our sample, increasing to 77 percent overall. Most variation in treaty commitments is found across countries. Yet, country-specific random effects models show that newly assumed treaty commitments in the period of analysis also drive restrictions on civil society (Appendix E). We note that if restrictions are effective in reducing reports about physical integrity rights violations, then reporting bias should make it harder to find evidence for our argument and the expectation of a positive relationship between restrictions and the PTS or Fariss's latent human rights abuses scores.

\footnotetext{
${ }^{12}$ Data on ratification come from the Office of the High Commissioner of Human Rights (2015).
} 


\section{Model Specification and Identification Strategy}

Our measure of restrictions is a discrete count variable. Therefore, we use a negative binomial count model. ${ }^{13}$ The Wooldridge (2002) test for panel autocorrelation indicated that the outcome variable, the count of restrictions, is serially correlated over time in all models. Therefore, as suggested by Murdie and Davis (2012), we use generalized estimating equation estimation with an autoregressive lag one correlation structure to account for auto-correlation in both coefficient estimates and standard errors.

Our analysis controls for potential confounders that influence physical integrity rights violations and are likely to also affect restrictions and governments' vulnerability to international costs. We account for the best predictors of physical integrity as identified by Hill and Jones (2014) rights violations - the number of constraints on the executive (Marshall, Gurr, and Jaggers 2016), judicial independence (Coppedge, Lindberg, Skaaning, and Teorell 2016; Coppedge et al. 2017, 59), and youth bulges (World Bank 2015) — and standard control variables used by Murdie and Davis (2012), capturing the influence of domestic and international civil society mobilization on human rights. That is, we also account for civil society activism with the logged count of protest events (lagged one year) because it may lead governments to use restrictions and pressure governments into ratifying human rights treaties. ${ }^{14}$ For domestic threats that may provide incentives for states to restrict civil society organizations and abuse human rights, we create a binary variable for whether a state experiences minor or major armed conflict (Gleditsch et al. 2002). We approximate capacity-related incentives to deliver on human rights commitments with z-standardized GDP per capita

\footnotetext{
${ }^{13}$ We do not use a Poisson model because the mean number of types of restriction (1.28) is smaller than the standard deviation (3.38). However, we note that our results hold when using a Poisson model.

${ }^{14}$ Data are obtained from Clark and Regan (2016).
} 
(in constant U.S. dollars) and population size (World Bank 2015). Summary statistics for all variables are in Appendix A. ${ }^{15}$

We address three further challenges to inference. First, we account for the nonrandom choice of governments to ratify a human rights treaty with an endogenous treatment model (von Stein 2005). That is, unobserved factors may be influencing both human rights treaty commitments and restrictions, such as prior domestic mobilization. The endogenous treatment model estimates three equations: an equation predicting selection into a human rights treaty, an equation predicting the occurrence of any restrictions in treaty member states, and an equation predicting the occurrence of any restrictions in non-member states. Holding constant observed and unobserved factors that influence both ratification and restrictions lets us estimate the effect of treaty ratification conditional on severe violations. We follow Conrad and Ritter $(2013,404)$ and use the number of intergovernmental organization memberships (IO) a state maintains during a given year as an instrument for treaty ratification. Results are very similar to the single-stage binomial count model (see Appendix L).

Second, there is the possibility of reverse causation. Our argument suggests that repressive governments use restrictions to mitigate (anticipated) international costs for physical integrity rights violations. Yet if governments observe that restrictions are effective in reducing monitoring, they may also have incentives to sign up to international human rights treaties. If civil society, indeed, chooses to refrain from mobilizing in response to restrictions, then a positive correlation between international human rights treaties and restrictions could be explained by the silencing effect of restrictions and the resulting lower costs for human rights-abusing governments to join international treaties. We test this possibility by examining if restrictions in the current

\footnotetext{
${ }^{15}$ We note that there might be other domestic causes of government-sponsored restrictions against civil society.
} 
and past year influence whether states ratified one of the human rights treaties, but we find no evidence for reverse causation (Appendix C).

Third, we are concerned about time trends in the human rights violations measures based on U.S. State Department reports (Clark and Sikkink 2013; Schnakenberg and Fariss 2014). Therefore, we estimate our results in a sample with observations after the turn of the century, when reporting bias should no longer affect over-time trends within countries (Poe, Carey, and Vazquez 2001, 677; Clark and Sikkink 2013, 555; see Appendix D). The results remain robust in this restricted sample.

\section{Findings}

The analysis provides evidence for our argument that governments prefer to keep information about their physical integrity rights violations private, especially if they are vulnerable to international pressures. Table 1 presents the results for international pressures resulting from ratification of the ICCPR. In line with our key theoretical expectation, Model 1A, without control variables, shows that the interaction effect between the Political Terror Scale - our measure for the severity of physical integrity violations - and the ratification of ICCPR is positive, but it just fails to reach conventional levels of significance. When controlling for observed confounders, the interaction term between ICCPR and the PTS is significant at the 95 percent confidence level. This finding holds when using Fariss's latent human rights scores for both the model without and with control variables (Models 2A and 2B). 
Table 1. Negative binomial model of restrictions against civil society, testing the impact of ICCPR ratification, 1994-2014

\begin{tabular}{|c|c|c|c|c|}
\hline \multirow[b]{2}{*}{ VARIABLES } & \multicolumn{2}{|c|}{ PTS } & \multicolumn{2}{|c|}{ Fariss } \\
\hline & Model 1A & Model 1B & Model 2A & Model 2B \\
\hline PTS & $\begin{array}{l}0.103+ \\
(0.059)\end{array}$ & $\begin{array}{l}-0.012 \\
(0.029)\end{array}$ & & \\
\hline ICCPR & $\begin{array}{l}-0.115 \\
(0.215)\end{array}$ & $\begin{array}{c}-0.472 * * \\
(0117)\end{array}$ & $\begin{array}{l}-0.037 \\
(0.057)\end{array}$ & $\begin{array}{c}-0.058 \\
(0.064)\end{array}$ \\
\hline PTS * ICCPR & $\begin{array}{c}0.050 \\
(0.063)\end{array}$ & $\begin{array}{c}0.162 * * \\
(0.031)\end{array}$ & & \\
\hline Latent human rights abuses score & & & $\begin{array}{c}0.239 * * \\
(0.041)\end{array}$ & $\begin{array}{c}0.037 \\
(0.058)\end{array}$ \\
\hline Latent abuses * ICCPR & & & $\begin{array}{c}0.034 \\
(0.041)\end{array}$ & $\begin{array}{l}0.144 * \\
(0.058)\end{array}$ \\
\hline Protest events (lag 1 year) & & $\begin{array}{c}0.019 * * \\
(0.006)\end{array}$ & & $\begin{array}{c}0.012 \\
(0.009)\end{array}$ \\
\hline Executive constraints & & $\begin{array}{c}-0.065^{* *} \\
(0.008)\end{array}$ & & $\begin{array}{c}-0.019+ \\
(0.011)\end{array}$ \\
\hline Youth bulge & & $\begin{array}{c}0.718 * * \\
(0.107)\end{array}$ & & $\begin{array}{c}0.588 * * \\
(0.202)\end{array}$ \\
\hline Independent judiciary & & $\begin{array}{c}-0.103 * * \\
(0.008)\end{array}$ & & $\begin{array}{c}-0.115^{* *} \\
(0.016)\end{array}$ \\
\hline Conflict year & & $\begin{array}{c}0.046^{* *} \\
(0.017)\end{array}$ & & $\begin{array}{c}-0.006 \\
(0.023)\end{array}$ \\
\hline GDP (stand.) & & $\begin{array}{c}0.080 * * \\
(0.020)\end{array}$ & & $\begin{array}{l}0.074 * \\
(0.035)\end{array}$ \\
\hline Population (stand.) & & $\begin{array}{c}0.054 * * \\
(0.008)\end{array}$ & & $\begin{array}{c}0.043 * * \\
(0.010)\end{array}$ \\
\hline Constant & $\begin{array}{l}-0.240 \\
(0.211)\end{array}$ & $\begin{array}{c}-2.627 * * \\
(0.342)\end{array}$ & $\begin{array}{c}-0.657 * * \\
(0.058)\end{array}$ & $\begin{array}{c}-2.386^{* *} \\
(0.600)\end{array}$ \\
\hline Observations & 3,001 & 2,730 & 3,146 & 2,593 \\
\hline Deviance & 3277 & 2137 & 2883 & 2001 \\
\hline
\end{tabular}

Notes: Standard errors in parentheses, $* * \mathrm{p}<0.01, * \mathrm{p}<0.05,+\mathrm{p}<0.1$.

Based on the estimates of Model 1B, Figure 4 illustrates that, all else being equal, governments that have ratified the ICCPR and score highest on the PTS employ the largest number of restrictions. This finding is substantively the same for predictions based on the estimated coefficients from Model 2B. In line with our argument, Figure 4 also shows that the predicted count of restriction types increases with the severity of physical integrity rights violations, but only if governments have ratified the ICCPR (black line). In contrast, restrictions neither increase nor decrease with the PTS if governments are not a party to the ICCPR. As illustrated in Figure 5, the marginal effect of the PTS is indeed positive and 
significant only among governments that ratified the ICCPR. Figure 6 shows that ratification of this human rights treaty increases restrictions for governments that score 5 on the Political Terror Scale. The average difference in restrictions due to ICCPR ratification is negative for countries under secure rule of law or with fewer physical integrity rights violations. Overall, these findings support our argument that internationally vulnerable states have the strongest incentives to hide severe human rights abuses.

The findings are very similar for the effect of physical integrity rights violations conditional on ratification of the Convention Against Torture (CAT), as shown in Models 3A, 3B, 4A, and 4B in Table 2. Based on the estimated coefficient in Model 3B, the graph in Figure 7 shows that the predicted number of restriction types is highest for governments that have ratified the CAT and commit the most severe physical integrity rights violations. Figure 8 illustrates that the marginal effect of the PTS on restrictions is positive only for the states that ratified the CAT, while it is non-significant for the states that have not signed this treaty. Figure 9 shows that ratifying the CAT has a positive effect on restrictions in human rights abusing regimes. However, CAT ratification reduces the number of restrictive practices and policies when governments generally comply with human rights treaties and commit no physical integrity rights violations. Overall, the figures present evidence in line with the argument that governments vulnerable to international pressure tend to impose restrictions on civil society organizations to stop the flow of information on physical integrity rights violations.

- Figure 4. Predicted number of restrictions (ICCPR)-

- Figure 5. Marginal effect of PTS -

- Figure 6. Marginal effect of ICCPR - 
Table 2. Negative binomial model of restrictions against civil society, testing the impact of CAT ratification, 1994-2014

\begin{tabular}{|c|c|c|c|c|}
\hline \multirow[b]{2}{*}{ VARIABLES } & \multicolumn{2}{|c|}{ PTS } & \multicolumn{2}{|c|}{ Fariss } \\
\hline & Model 3A & Model 3B & Model 4A & Model 4B \\
\hline PTS & $\begin{array}{c}0.073 \\
(0.045)\end{array}$ & $\begin{array}{l}-0.007 \\
(0.025)\end{array}$ & & \\
\hline CAT & $\begin{array}{l}-0.156 \\
(0.170)\end{array}$ & $\begin{array}{c}-0.611 * * \\
(0.102)\end{array}$ & $\begin{array}{c}0.048 \\
(0.050)\end{array}$ & $\begin{array}{l}0.136^{*} \\
(0.060)\end{array}$ \\
\hline $\mathrm{PTS} * \mathrm{CAT}$ & $\begin{array}{c}0.081 \\
(0.051)\end{array}$ & $\begin{array}{c}0.208 * * \\
(0.027)\end{array}$ & & \\
\hline Latent human rights abuses score & & & $\begin{array}{c}0.201 * * \\
(0.030)\end{array}$ & $\begin{array}{c}0.127 * * \\
(0.040)\end{array}$ \\
\hline Latent abuses * CAT & & & $\begin{array}{c}0.018 \\
(0.030)\end{array}$ & $\begin{array}{c}0.162 * * \\
(0.046)\end{array}$ \\
\hline Protest events (lag 1 year) & & $\begin{array}{c}0.053^{* *} \\
(0.008)\end{array}$ & & $\begin{array}{c}0.004 \\
(0.008)\end{array}$ \\
\hline Executive constraints & & $\begin{array}{c}-0.059 * * \\
(0.009)\end{array}$ & & $\begin{array}{c}-0.055^{* *} \\
(0.010)\end{array}$ \\
\hline Youth bulge & & $\begin{array}{c}0.116 \\
(0.077)\end{array}$ & & $\begin{array}{l}1.331 * * \\
(0.169)\end{array}$ \\
\hline Independent judiciary & & $\begin{array}{c}-0.150 * * \\
(0.009)\end{array}$ & & $\begin{array}{c}-0.183^{* *} \\
(0.013)\end{array}$ \\
\hline Conflict year & & $\begin{array}{c}0.012 \\
(0.013)\end{array}$ & & $\begin{array}{c}0.062 * * \\
(0.017)\end{array}$ \\
\hline GDP (stand.) & & $\begin{array}{l}0.023 * \\
(0.012)\end{array}$ & & $\begin{array}{c}0.127 * * \\
(0.026)\end{array}$ \\
\hline Population (stand.) & & $\begin{array}{c}0.070 * * \\
(0.004)\end{array}$ & & $\begin{array}{c}0.094 * * \\
(0.016)\end{array}$ \\
\hline Constant & $\begin{array}{l}-0.148 \\
(0.163)\end{array}$ & $\begin{array}{c}-1.015 * * \\
(0.274)\end{array}$ & $\begin{array}{c}-0.682 * * \\
(0.055)\end{array}$ & $\begin{array}{c}-4.751 * * \\
(0.531)\end{array}$ \\
\hline Observations & 2,872 & 2,730 & 2,995 & 2,480 \\
\hline Deviance & 3176 & 2215 & 2777 & 1775 \\
\hline
\end{tabular}

Notes: Standard errors in parentheses, $* * \mathrm{p}<0.01, * \mathrm{p}<0.05,+\mathrm{p}<0.1$

- Figure 7. Predicted number of restrictions $(C A T)-$

- Figure 8. Marginal effect of PTS -

- Figure 9. Marginal effect of CAT -

What is the substantive significance of these relationships? Table 3 compares the average marginal effects of treaty ratification in human rights-abusing regimes to those of the other 
independent variables. All else equal, ICCPR ratification among states that severely violate human rights $(\mathrm{PTS}=5)$ increases restrictions on civil society by roughly 0.784 types. The effect roughly corresponds to the effect of a 35 standard deviations-increase in protest events (about 170 events) or five standard deviations-increase in GDP per capita (about 64,178 constant U.S. dollars). CAT ratification among states that severely violate human rights (PTS=5) increases the average number of restriction types by 1.165 types. This effect corresponds to the effect of a 53 standard deviations-increase in protest (about 258 events) and a 10 standard deviations-increase in GDP per capita (about 160,455 constant U.S. dollars). Moreover, human rights violations conditional on CAT and ICCPR ratification have the largest effect sizes among the continuous variables. Other determinants are also important, especially executive constraints, independent judiciaries, and youth bulges.

Table 3. Marginal effects (based on Model 1B)

\begin{tabular}{lc}
\hline & $\begin{array}{c}\text { Average marginal effect } \\
\text { for one st.dev. increase }\end{array}$ \\
\hline ICCPR (Political Terror Scale = 1) & $-0.330^{*}$ \\
ICCPR (Political Terror Scale = 5) & $0.784^{*}$ \\
CAT (Political Terror Scale = 1)+ & $-0.368^{*}$ \\
CAT (Political Terror Scale = 5)+ & $1.165^{*}$ \\
Political Terror Scale (ICCPR not ratified) & 0.019 \\
Political Terror Scale (ICCPR ratified) & $0.271^{*}$ \\
Political Terror Scale (CAT not ratified)+ & -0.011 \\
Political Terror Scale (CAT ratified)+ & $0.349^{*}$ \\
Protest events (lag 1 year) & $0.022^{*}$ \\
Executive constraints & $-0.158^{*}$ \\
Youth bulge & $0.197^{*}$ \\
Independent judiciary & $-0.114^{*}$ \\
Conflict year & $0.021^{*}$ \\
GDP (stand.) & $0.115^{*}$ \\
Population (stand.) & $0.074^{*}$ \\
\hline
\end{tabular}

Notes: + based on Model 3B, * significant within 95\% confidence interval.

For the control variables, the findings are in line with previous expectations. The measure for protest events is always positive and mostly reaches conventional levels of significance. That is, contentious action of civil society leads governments to impose more 
restrictions, yet the effect is substantively small. Controlling for civil society mobilization should alleviate concerns that there is a spurious correlation between physical integrity rights violations and the prevalence of restrictions. Regimes with more executive constraints and independent judiciary impose significantly fewer restrictions. Youth bulges significantly increase restrictions. We do not find that armed conflicts are consistently associated with greater restrictions against civil society. Yet, the effect of armed conflict becomes significantly positive if we exclude the Political Terror Scale. Finally, the coefficients for GDP per capita and population size are non-significant or positive, suggesting that economic development makes governments more sensitive to civil society monitoring or more capable of imposing restrictions on civil society monitoring. ${ }^{16}$

\section{Robustness Tests}

Our results remain robust after excluding all cases before 2000 to avoid reporting bias (Appendix D) and are substantively the same for a different model specification, including a pooled negative binomial model and a country-specific random effects negative binomial model estimated with Maximum Likelihood estimation (Appendix E). We also create a measure that is 1 for governments that have ratified the ICCPR or the CAT, and 0 otherwise, as well as a measure for number of treaties that a government has ratified, ranging from 0 to 2. Our substantive findings do not change (Appendix F). Finally, we examine our results by using a related but conceptually different operationalization of restrictions on civil society organizations to alleviate concerns that our results are driven by our measure for the dependent variable (Appendix G). To that end, we use the V-Dem project's data on government attempts to repress civil society. We invert the original measure so that it ranges between 0 for no restrictions and 4 for violent persecution of all members of independent

\footnotetext{
${ }^{16} \mathrm{We}$ thank the anonymous reviewer for the alternative interpretations.
} 
civil society organizations. The analyses reproduce our main findings for the interaction between the human rights treaties and the Fariss's latent human rights abuses scores. The non-significant coefficients of the interactions between the human rights violations measures and CAT point in the expected direction. These findings are noteworthy as the V-Dem measure includes high-visibility practices, such as the disruption of public gatherings or the liquidation of civil society organizations (Pemstein 2015; Coppedge et al. 2017, 243). The results suggest that repressive and governments vulnerable to international pressure use more or less subtle practices to silence voices that could lead to international costs for their abuses.

\section{Conclusion}

Our analyses show that states that have ratified human rights treaties impose restrictions on human rights defenders if they have severe human rights violations to hide. Existing research tells us that civil society organizations monitor states' implementation of treaty obligations and inform the international community about non-compliance. This monitoring activity is costly for states. We examine a theoretical implication of this line of research. States have an interest in reducing the cost of repression. Instead of improving their human rights behavior to live up to their treaty commitments, governments seek to make repression less visible by imposing restrictions on civil society organizations.

UN officials and others point to the "shrinking" of civil society space. Yet to date, neither policy makers nor scholars have a good understanding of how systematically states interfere with civil society, the specific measures that they use and which states are most likely to behave in this strategic way. Our new cross-country Civil Society Restrictions Dataset allow scholars to address these questions. These data allow researchers to explore the variety of types of restrictions governments may impose. Future research might investigate the clustering of types of restrictions, transborder diffusion and the impact of these measures on the flow of information. 
For the international community, the findings underline the concerns expressed by UN officials and others about closing civil society space. Our study does not suggest that human rights treaties directly worsen the human rights situation. Instead, we contend that these international instruments and resulting pressures on repressive states create a perverse incentive that may have unintended, negative consequences for civil society activity. Our results should prompt international and domestic policy-makers and human rights practitioners to pay more specific attention to the range of types of restrictions, some of which in isolation may seem relatively benign, on those that monitor and report on human rights. Recently, the UN Human Rights Council considered this issue by passing Resolution 32/31 on Civil Society Space (2016). This resolution recognized "the crucial importance of the active involvement of civil society ... in promoting good governance, including through transparency and accountability," and it emphasized first and foremost "that creating and maintaining a safe and enabling environment in which civil society can operate free from hindrance and insecurity assists States in fulfilling their existing international human rights obligations and commitments." Our research would suggest that this type of focused international attention to the harm done by restrictions can help protect civil society and the sustained delivery of public goods. 


\section{REFERENCES}

Appel, Benjamin J. 2016. "In the Shadow of the International Criminal Court: Does the ICC Deter Human Rights Violations?” Journal of Conflict Resolution 62 (1): 3-28.

Baron, David P. 2009. "A Positive Theory of Moral Management, Social Pressure, and Corporate Social Performance." Journal of Economics and Management Strategy 18 (1): 743.

Bennett, Karen, Danna Ingleton, Alice M. Nah, and James Savage. 2015. "Critical Perspectives on the Security and Protection of Human Rights Defenders." The International Journal of Human Rights 19 (7): 883-95.

Bob, Clifford. 2005. The Marketing of Rebellion: Insurgents, Media, and International Activism. Cambridge, UK: Cambridge University Press.

Brechenmacher, Saskia, and Thomas Carothers. 2014. Closing Space: Democracy and Human Rights Support Under Fire. Washington, D.C.: Carnegie Endowment for International Peace.

Brysk, Alison. 2013. Speaking Rights to Power: Constructing Political Will. Oxford, UK: Oxford University Press.

Carothers, Thomas. 2016. "Closing Space for International Democracy Promotion and Human Rights Support.” Journal of Human Rights Practice 8 (3): 358-77.

Christensen, Darin, and Jeremy M. Weinstein. 2013. "Defunding Dissent: Restrictions on Aid to NGOs." Journal of Democracy 24 (2): 77-91.

Cingranelli, David L., David L. Richards, and Chad K. Clay. 2014. "The CIRI Human Rights Dataset" (version 2014.04.14). http://www.humanrightsdata.com.

Cingranelli, David L., and Mikhail Filippov. 2018. "Are Human Rights Practices Improving?” American Political Science Review 112 (4): 1083-1089.

Clark, David, and Patrick Regan. 2016. "Mass Mobilization Protest Data." Harvard Dataverse, V2. Accessed June 13, 2018. https://doi.org/10.7910/dvn/httwyl.

Clark, Ann Marie, and Kathryn Sikkink. 2013. "Information Effects and Human Rights Data: Is the Good News about Increased Human Rights Information Bad News for Human Rights Measures?" Human Rights Quarterly 35 (3): 539-68.

Conrad, Courtney R., and Emily Hencken Ritter. 2013. "Treaties, Tenure, and Torture: The Conflicting Domestic Effects of International Law." The Journal of Politics 75 (2): 397-409.

Coppedge, Michael, Staffan L. Lindberg, Sven-Erik Skaaning, and Jan Teorell. 2016. "Measuring High Level Democratic Principles using the V-Dem Data." International Political Science Review 37 (5): 580-93.

Coppedge, Michael, John Gerring, Staffan I. Lindberg, Svend-Erik Skaaning, Jan Teorell, 
David Altman, Frida Andersson, Michael Bernhard, M. Steven Fish, Adam Glynn, Allen Hicken, Carl Henrik Knutsen, Kyle L. Marquardt, Kelly McMann, Valeriya Mechkova, Pamela Paxton, Daniel Pemstein, Laura Saxer, Brigitte Seim, Rachel Sigman, and Jeffrey Staton. 2017. "Varieties of Democracy (V-Dem) Codebook v7." Accessed May 6, 2017. https://www.v-dem.net/en/reference/version-7-may-2017/.

Dai, Xinyuan. 2005. "Why Comply? The Domestic Constituency Mechanism." International Organization 59 (2): 363-98.

Dai, Xinyuan. 2013. "The "Compliance Gap" and the Efficacy of International Human Rights Instititutions." In The Persistent Power of Human Rights: From Commitment to Compliance, edited by Thomas Risse, Stephen C. Ropp and Kathryn Sikkink, 85-02. Cambridge, UK: Cambridge University Press.

Dupuy, Kendra, James Ron, and Aseem Prakash. 2016. "Hands off My Regime! Governments' Restrictions on Foreign Aid to Non-Governmental Organizations in Poor and Middle-Income Countries." World Development 84: 299-11.

Fariss, Christopher J. 2014. "Respect for Human Rights Has Improved Over Time: Modeling the Changing Standard of Accountability." American Political Science Review 108 (2): 29718.

Fariss, Christopher J. 2019. "Yes, Human Rights Practices Are Improving Over Time." American Political Science Review (Online First): 1-14. Doi:10.1017/s000305541900025x.

Glasius, Marlies. 2018. "What Authoritarianism Is ... and Is Not: A Practice Perspective." International Affairs 94 (3): 515-33.

Gibney, Mark, Linda Cornett, Reed Wood, Peter Haschke, and Daniel Arnon. 2016. "The Political Terror Scale 1976-2015.” Accessed December 20, 2016.

http://www.politicalterrorscale.org.

Gleditsch, Nils Petter, Peter Wallensteen, Mikael Eriksson, Margareta Sollenberg, and Håvard Strand. 2002. “Armed Conflict 1946-2001: A New Dataset.” Journal of Peace Research 39 (5): 615-38.

Hafner-Burton, Emily. 2008. "Sticks and Stones: Naming and Shaming the Human Rights Enforcement Problem.” International Organization 62 (4): 689-716.

Hafner-Burton, Emilie M., and Kiyoteru Tsutsui. 2005. "Human Rights in a Globalizing World: The Paradox of Empty Promises." American Journal of Sociology 110 (5): 13731411.

Hathaway, Oona A. 2002. "Do Human Rights Treaties Make a Difference?" The Yale Law Journal 111 (8): 1935-2042.

Hendrix, Cullen S., and Wendy H. Wong. 2012. "When Is the Pen Truly Mighty? Regime Type and the Efficacy of Naming and Shaming in Curbing Human rights Abuses." British Journal of Political Science 43 (3): 651-72. 
Hill, Daniel W., and Zachary M. Jones. 2014. "An Empirical Evaluation of Explanations for State Repression.” American Political Science Review 108 (3): 661-87.

Holmes, Oliver, “Amnesty Calls Off Thai Torture Report After Police Warning”. The Guardian. September 28, 2016. https://www.theguardian.com/world/2016/sep/28/amnestythailand-torture-report-launch-cancelled-police-warning.

Human Rights First/Lawyers Committee for Human Rights. 2004. "The Role of Human Rights NGOs in Relation to ICC investigations." Discussion Paper. Accessed June 22, 2018. https://www.globalpolicy.org/images/pdfs/0904hrficc.pdf.

International Center for Not-for-Profit Law. 2016. "Civic Freedom Monitor.” Accessed November 2, 2016. http://www.icnl.org/research/monitor.

Keck, Margaret E., and Kathryn Sikkink. 1998. Activists beyond Borders. Advocacy Networks in International Politics. Ithaca, N.Y.: Cornell University Press.

Krain, Mathew. 2012. 'J'accuse! Does Naming and Shaming Perpetrators Reduce the Severity of Genocides or Politicides?" International Studies Quarterly 56 (3): 574-89.

Landman, Todd. 2005. Protecting Human Rights: A Comparative Study. Washington, D.C.: Georgetown University Press.

Litvinova, Dara. 'Labeled as 'Foreign Agent,' Russian NGO Committee Against Torture Shuts Its Doors." Moscow Times. July 26, 2015.

https://www.themoscowtimes.com/2015/07/26/labeled-as-foreign-agent-russian-ngocommittee-against-torture-shuts-its-doors-a48526.

Luhn, Alice. 'National Endowment for Democracy is First 'Undesirable' NGO Banned in Russia." The Guardian. July 18, 2015.

https://www.theguardian.com/world/2015/jul/28/national-endowment-for-democracybanned-russia.

Lupu, Yonatan. 2013. "Best Evidence: The Role of Information in Domestic Judicial Enforcement of International Human Rights.” International Organization 67 (3): 469-503.

Marshall, Monty G., Gurr, Ted Robert, and Keith Jaggers. 2016. POLITY IV Project. Political Regime Characteristics and Transitions, 1800-2015. V.p4v2015d. Accessed November 2, 2016. http://www.systemicpeace.org/polity/.polity4.htm.

McCormick, James M., and Neil J. Mitchell. 1997. "Human Rights Violations, Umbrella Concepts, and Empirical Analysis." World Politics 49 (4): 510-25.

Meernik, James, Rosa Aloisi, Marsha Sowell, and Angela Nichols. 2012. "The Impact of Human Rights Organizations on Naming and Shaming." Journal of Conflict Resolution 56 (2): 233-56.

Moravscik, Andrew. 2000. "The Origins of Human Rights Regimes: Democratic Delegation in Postwar Europe." International Organization 54 (2): 217-52. 
Murdie, Amanda M., and David R. Davis. 2012. "Shaming and Blaming: Using Events Data to Assess the Impact of Human Rights INGOs." International Studies Quarterly 56 (1): 1-16.

Nechepurenko, Ivan. "Russian Elections Monitor Golos Sees Offices, Staff Homes

Searched." The Moscow Times. July 7, 2015.

https://www.themoscowtimes.com/2015/07/07/russian-elections-monitor-golos-sees-officesstaff-homes-searched-a47974.

Neumayer, Eric. 2005. "Do International Human Tights Treaties Improve Respect For Human Rights?” Journal of Conflict Resolution 49 (6): 925-53.

Office of the High Commissioner of Human Rights. 2015. "Status of Ratification. Interactive Dashboard." Accessed November 2, 2016. http://indicators.ohchr.org.

Payne, Caroline, and Rodwan M. Abouharb. 2016. "The International Covenant on Civil and Political Rights and Strategic Shift to Forced Disappearance." Journal of Human Rights 15 (2): $1-26$.

Pemstein, Daniel. 2015. “CSO participatory environment." V-Dem Working Paper Series 21. Gothenburg: V-Dem Institute, University of Gothenburg; Notre Dame: Helen Kellogg Institute for International Studies, University of Notre Dame.

Poe, Steven C., Sabine C. Carey, and Tanya C. Vazquez. 2001. "How are These Pictures Different? A Quantitative Comparison of the US State Department and Amnesty International Human Rights Reports, 1976-1995.” Human Rights Quarterly 23 (3): 650-77.

Risse, Thomas, and Kathryn Sikkink. 1999. "The Socialization of International Human Rights Norms into Domestic Practices: Introduction." In The Power of Human Rights: International Norms and Domestic Change, edited by Thomas Risse, Stephen C. Ropp, and Kathryn Sikkink, 1-38. Cambridge, UK: Cambridge University Press.

Risse, Thomas, Stephen C. Ropp, and Kathryn Sikkink. 2013. The Persistent Power of Human Rights. From Commitment to Compliance. Cambridge, UK: Cambridge University Press.

Ritter, Emily Hencken, and Courtenay R. Conrad. 2016. "Human Rights Treaties and Mobilized Dissent Against the State." Review of International Organization 11 (4): 449-75.

Schnakenberg, Keith, and Christopher J. Fariss. 2014a. "Dynamic Patterns of Human Rights Practices." Political Science Research and Methods 2 (1): 1-31.

— 2014b. "Latent Human Rights Scores (version 2).” Accessed November 2, 2016. http://humanrightsscores.org/.

Sekaggya, Margaret. 2013. "Report of the Special Rapporteur on the Situation of Human Rights Defenders." A/HRC/25/55. December 23, 2013. Geneva: Office of the United Nations High Commissioner for Human Rights. Accessed May 10, 2015. http://www.ohchr.org/EN/HRBodies/HRC/RegularSessions/Session25/Pages/ListReports.asp $\mathrm{x}$. 
Simmons, Beth. 2009. Mobilizing for Human Rights. Cambridge, UK: Cambridge University Press.

Simmons, Beth A., and Allison Danner. 2010. "Credible Commitments and the International Criminal Court.” International Organization 64 (2): 225-56.

Smidt, Hannah M., Dominic Perera, Neil J. Mitchell, and Kristin M. Bakke. 2020. "Silencing Their Critics: How Effective Are Governments in Restricting Civil Society?" British Journal of Political Science, forthcoming.

Smith-Cannoy, Heather. 2012. Insincere Commitments: Human Rights Treaties, Abusive States, and Citizen Activism. Washington, D.C.: Georgetown University Press.

Snyder, Sarah B. 2011. Human Rights Activism and the End of the Cold War: A

Transnational History of the Helsinki Network. Cambridge. UK: Cambridge University Press.

Tavernise, Sabrina. "MacArthur Foundation to Close Offices in Russia." The New York Times. July 22, 2015. https://www.nytimes.com/2015/07/23/world/europe/macarthurfoundation-to-close-offices-in-russia.html.

Thomas, Daniel. 2001. The Helsinki Effect: International Norms, Human Rights, and the Demise of Communism. Princeton, NJ: Princeton University Press.

U.S. Department of State. 2005. "Country Reports on Human Rights Practices for 2005. Uganda.” Washington, D.C.: U.S. Department of State. Accessed July 2, 2017. https://www.state.gov/j/drl/rls/hrrpt/2005/61598.htm.

— 2009. "Country Reports on Human Rights Practices for 2008. Guinea.” Washington, D.C.: U.S. Department of State. Accessed November 2, 2016. http://www.state.gov/j/drl/rls/hrrpt/2008/af/119005.htm.

— 2015. "Country Reports on Human Rights Practices for 2015. Belarus." Washington, D.C.: U.S. Department of State. Accessed November 2, 2016. http://papublic.state.gov/mystatedept/reports/pdfreport_5189.pdf.

Von Stein, Jana. 2005. "Do treaties constrain or screen? Selection bias and treaty compliance." American Political Science Review 99 (4): 611-22.

Vreeland, James R. 2008. "Political Institutions and Human Rights: Why Dictatorships Enter into the United Nations Convention against Torture." International Organization 62 (1): 65101.

Wooldridge, Jeffrey M. 2002. Econometric Analysis of Cross Section and Panel Data.

Cambridge, MA: MIT Press

World Bank. 2015. "World Development Indicators." Washington, D.C.: The World Bank. Accessed November 2, 2016. http://data.worldbank.org/data-catalog/world-developmentindicators. 